\title{
Materi Bahasa Indonesia Kelas 4 SD (Menemukan Ide Pokok dan Paragaraf)
}

\author{
Nuraini* \\ Email : nuraini0603@student.unri.ac.id \\ *Program Studi Pendidikan Bahasa dan Sastra Indonesia, Universitas Riau
}

\section{Pengantar}

Dalam kehidupan sehari-hari manusia meakukan kegiatan kegiatan berkomunikasi. Pada saat melakukan kegiatan berkomunikasi tersebut, manusia menggunakan bahasa sebagai sarana penunjangnya. Bahasa adalah alat komunikasi yang memiliki peranan yang sangat penting dalam kehidupan manusia. Apabila manusia tidak memiliki kemampuan berbahasa, manusia akan kesulitan mengungkapkan perasaan, ide dan pendapatnya. Dengan bahasa manusia dapat menyampaikan pikiran dan gagasan dengan orang lain baik secara lisan maupun tulisan. Pembelajaran bahasa Indonesia diarahkan untuk meningkatkan kemampuan siswa dalam berkomunikasi menggunakan Bahasa Indonesia secara baik dan benar yang meliputi empat aspek keterampilan berbahasa. Apabila sala satu keterampilan tidak dikuasai siswa maka itu akan berpengaruh terhadap keterampilan berbahasa lainnya seperti: (a) menyimak, (b) berbicara, (c) membaca dan keterampilan (d) menulis. Keempat jenis keterampilan tersebut saling berhubungan dan mendukung perkembangan satu sama lain. Siswa yang tidak memiliki keterampilan membaca dan minat yang rendah dalam membaca, maka ia akan kesulitan untuk menulis. Sebalinya, siswa yang memiliki keterampilan membaca yang baik dapat menghasilkan tulisan berkualitas tinggi dan juga memiliki kemampuan berbicara yang sangat baik karena wawasan luas yang dimilikinya. Kemampuan bahasa itu dikelompokkan menjadi dua, yaitu kemampuan bahasa pasif-reseptif dan kemampuan bahasa aktif produktif. Kemampuan bahasa pasif reseptif dikaitkan dengan kemampuan menyimak dan kemampuan membaca sedangkan kemampuan berbicara dan kemampuan menulis dikelompokkan kedalam kemampuan aktif produktif. Kegiatan reseptif menyimak dan membaca memiliki persamaan yaitu sama-sama kegiatan yang bertujuan untuk memahami informasi. Keterampilan membaca menjadi dasar membaca yang tercantum adalah menemukan ide pokok dalam wacana yang dibaca. Berdasarkan kompetensi dasar tersebut siswa diharapkan: (1) Mampu memahami hakikat dan ciri-ciri ide pokok, (2) Mampu menunjukkan letak ide pokok dalam suatu bacaan pada wacana, (3) Mampu mengungkapkan ide pokok dalam setiap bacaan pada suatu wacana. Pembelajaran 
menemukan ide pokok itu penting karena untuk dapat memahami apa yang ingin disampaikan oleh penulis, pembaca harus mampu menemukan ide pokok dari bacaan/wacana yang dibaca. Guru diharapkan mampu membangkitkan minat dan semangat siswa dalam proses membaca untuk menemukan ide pokok. Pembelajaran menemukan ide pokok dalam bacaan/wacana telah diajarkan kepada siswa, tetapi pada kenyataannya masih banyak siswa khususnya kelas IV SD yang belum mampu menemukan ide pokok dalam bacaan/wacana dengan benar. Salah satu upaya untuk meningkatkan kemampuan menemukan ide pokok dalam bacaan/wacana adalah dengan cara penelitian yang akar permasalahannya muncul di kelas, dan dirasakan langsung oleh guru yang bersangkutan. Jenis inovasi ini sangat bermanfaat sebagai upaya untuk memperbaiki proses pembelajaran di kelas bagi siswa kelas iv sekolah dasar.

\section{Tindakan yang Dilakukan}

\section{a. Kesiapan Pengajar}

Proses Setiap manusia yang dilahirkan dibekali dengan kemampuan dasar. Kemampuan dasar ini ini tumbuh dan berkembang bila dibina dan dilatih. Sebaliknya, kemampuan dasar itu menjadi tumpul bila tidak dibina. Dalam belajar, diperlukan keterampilan intelektual, sosial, dan fisik. Ketiga keterampilan inilah yang mendasari pembelajaran dengan pendekatan keterampilan proses. Setiap keterampilan terdiri atas beberapa subketerampilan yang perlu dilatihkan. Keterampilan proses berfungsi sebagai alat menemukan dan mengembangkan konsep. Konsep yang telah ditemukan dan dikembangkan berfungsi sebagai penunjang keterampilan proses. Interaksi antara pengembangan keterampilan proses dengan pengembangan konsep dalam pembelajaran mengahasilkan terbentuknya sikap dan nilai dalam. diri siswa. Sikap dan nilai tersebut misalnya teliti, kreatif, kritis, objektif, tenggang rasa, bertanggung jawab, jujur, terbuka, dapat bekerjasama, rajin dan sebagainya. Keterampilan proses dibangun oleh sejumlah keterampilanketerampilan.Karena itu pencapaian atau pengembangannya dilaksanakan dalam setiap proses belajar mengajar dalam semua mata pelajaran. Sehingga berdasarkan itu dibutuhkan kemampuan pengajar untuk memberikan metode yang mampu membuat siswa untuk mampu menyerap pembelajaran dengan mudah, Berdasarkan sebuah buku metode dan model pembelajaran yang ditujukan untuk guru sekolah dasar yaitu menggunakan sebuah metode:

a. Kegiatan Membaca Berpikir Terarah (Model Directed Reading Thinking Activity) (DRTA) Langkah-Iangkah Kegiatan Membaca Berpikir Terarah adalah sebagai berikut:

1) Tahap Prabaca 
(a) Lembar prediksi berisi klasifikasi, seperti kolorn terbukti. tidak terbukti, benar- salah, informasi tidak cukup, atau lainnya.

(b) Menentukan tujuan membaca (apakah terbukti atau tidak prediksinya)

(c) Lanjutan

2) Tahap membaca

(a) Membaca teks (diarn/nyaring)

b) Memberi tanda (X) pada lembar klarifikasi pada lembar prediksi dan menentukan berapa banyak kesesuaian hasil prediksi dengan isi bacaan

3) Pasca Membaca

(a) Membanding isi prediksi dengan isi teks yang sebenarnya

(b) Menganalisis daftar prediksi dan menilai berapa banyak kesesuaian hasil prediksi dengan isi bacaan.

\section{b. Kesiapan siswa untuk belajar}

Perekayasaan proses pembelajaran dapat didesain oleh guru sedemikian rupa. Idealnya pendekatan pembelajaran untuk siswa pandai harus berbeda dengan kegiatan siswa berkemampuan sedang atau kurang walaupun untuk memahami konsep yang sama karena setiap siswa mempunyai keunikan masing-masing. Hal ini menunjukkan bahwa pemahaman guru terhadap pendekatan, model, strategi, metode dan teknik pembelajaran tidak bisa diabaikan. Komponen membuka pelajaran menurut Uzer Usman adalah sebagai berikut :

1) Menarik perhatian siswa dengan gaya mengajar, penggunaan media pembelajaran dan pola interaksi pembelajaran yang bervariasi.

2) Menimbulkan motivasi, disertasi kehangatan dan keantusiasan, menimbulkan rasa ingin tahu, mengemukakan ide yang bertentangan, dan memperhatikan minat atau interes siswa.

3) Memberi acuan melalui berbagai usaha seperti mengemukakan tujuan pembelajaran dan batas-batas tugas, menyarankan langkah-langkah yang akan dilakukan, mengingatkan masalah pokok yang akan dibahas, dan mengajukan beberapa pertanyaan.

4) Memberikan apersepsi (memberikan kaitan antara materi sebelumnya dengan materi yang akan dipelajari) sehingga materi yang dipelajari merupakan suatu kesatuan yang utuh yang tidak terpisah-pisah.

\section{c. Pembelajaran daring pada materi Menentukan Ide Pokok Paragraf}

Menurut Sudarso (2001) keterampilan membaca sebagai salah satu aktivitas yang sangat komplek. Tidak hanya melibatkan kemampuan membaca, tetapi juga melibatkan kemampuan kognitif, kemampuan untuk mengamati dan atau kemampuan berkomunikasi. Tidak hanya itu, kemampuan motorik juga menentukan keterampilan membaca. Salah satu indikator peserta didik telah 
mampu menguasai ketrampilan membaca manakala dapat menemukan gagasan pokok dan gagasan pendukung pada sebuah paragraf dalam bacaan. Namun kendala yang dihadapi oleh penulis saat mengajarkan materi tentang menemukan gagasan pokok dan gagasan pendukung di kelas 4 SD dengan model ceramah dan penugasan dalam pembelajaran Jarak Jauh (PJJ) hasilnya belum sesuai harapan. Dari peserta didik kelas 4 yang berjumlah 7 orang hanya ada 2 peserta didik yang mampu menemukan gagasan pokok dan gagasan pendukung dengan tepat. Upaya mengatasi masalah yang dialami penulis tersebut maka penulis mengubah model pembelajaran dengan menerapkan model pembelajaran, Cooperative Integrated Reading And Composition (CIRC). Model pembelajaran Cooperative Integrated Reading and Composition-CIRC (Kooperatif Terpadu. Membaca dan Menulis) merupakan model pembelajaran khusus Mata pelajaran Bahasa Indonesia dalam rangka membaca dan menemukan ide pokok, pokok pikiran atau,tema sebuah wacana/kliping. dapat dikategorikan pembelajaran terpadu. Menurut Fogarty (1991), berdasarkan sifat keterpaduannya, pembelajaran terpadu dapat dikelompokkan menjadi: 1) model dalam satu disiplin ilmu yang meliputi model connected (keterhubungan) dan model nested (terangkai); 2) model antar bidang studi yang meliputi model sequenced (urutan), model shared (perpaduan), model webbed (jaring laba-laba), model theaded (bergalur) dan model integreted (terpadu); 3) model dalam lintas siswa. Langkah-langkah pembelajarannya sebagai berikut : pertama, Membentuk kelompok yang anggotanya 4 orang peserta didik secara heterogen. Kedua, Guru memberikan wacana/kliping sesuai dengan topik pembelajaran. Ketiga, peserta didik bekerja sama saling membacakan dan menemukan ide pokok dan memberi tanggapan terhadap wacana/kliping dan ditulis pada lembar kertas. Keempat, peserta didik mempresentasikan/membacakan hasil kelompok. Kelima, guru dan siswa membuat kesimpulan bersama. Dengan melaksanakan langkahlangkah model pembelajaran Cooperative Integrated Reading And Composition (CIRC) maka pembelajaran menjadi lebih menyenangkan dan memudahkan peserta didik dalam menemukan gagasan pokok dan gagasan pendukung. Hal ini ditunjukkan dengan hasil penilaian akhir pembelajaran dari 7 peserta didik kelas IV SDsudah mampu menemukan gagasan pokok dan gagasan pendukung dari bacaan disajikan guru melalui share screen saat pembelajaran daring menggunakan Google teem dengan baik. Berdasarkan pengalaman penulis tersebut, dapat disimpulkan bahwa penggunaan model pembelajaran Cooperative Integrated Reading And Composition (CIRC) dapat meningkatkan kemampuan peserta didik menemukan gagasan pokok dan gagasan pendukung kelas IV SD. Simpulan tersebut nantinya dapat dibuktikan 
dengan adanya data peningkatan nilai pada evaluasi muatan pelajaran Bahasa Indonesia metode Cooperative Integrated Reading And Composition (CIRC)

\section{Sarana Pendukung}

Pengertian sarana adalah segala sesuatu yang dipakai sebagai alat untuk mencapai makna dan tujuan (Kamus Besar Bahasa Indonesia,2008). Sebagai contoh: sarana pendidikan diartikan sebagai alat untuk mencapai tujuan pendidikan, misalkan buku, tas, pulpen, komputer, dll

\section{a. Google classroom}

Google Classroom adalah bagian dari G Suite for Education yang juga hadir dalam versi aplikasi seluler. Untuk menggunakannya, pengajar dan murid wajib memiliki akun Google agar saling terhubung. Selain itu, lantaran bagian dari G Suite, Google Classroom terikat bersama Drive, Calender, Form, Jamboard, Hangouts Meet, Docs, Sheets, Slide, termasuk Gmail. Artinya, layanan-layanan itu dapat dimanfaatkan dalam proses pembelajaran. Fungsi Google Classroom Google Classroom memungkinkan kegiatan belajar mengajar menjadi lebih produktif dan bermakna dengan menyederhanakan tugas, meningkatkan kolaborasi, dan membina komunikasi. Pengajar dapat membuat kelas, memberikan tugas, mengirim masukan, dan melihat semuanya di satu tempat. Sekolah dan lembaga nonprofit mendapatkan Google Classroom sebagai layanan inti G Suite for Education dan G Suite for Nonprofits secara gratis. Setiap orang yang memiliki akun Google pribadi juga dapat menggunakan Classroom secara gratis. Untuk organisasi, Google Classroom adalah layanan tambahan dalam produk G Suite seperti G Suite Enterprise atau G Suite Business. Baca juga: Daftar E-Learning Kemendikbud, Sekolah Online untuk Mencegah Corona E-Learning Saat Social Distancing, Telkomsel Beri Kuota 30GB Gratis Daftar 7 Perguruan Tinggi Indonesia yang Punya Sistem E-Learning Fitur Google Classroom Google Classroom dapat disiapkan dengan mudah. Pengajar dapat menyiapkan kelas dan mengundang siswa serta asisten pengajar. Di halaman Tugas Kelas, mereka dapat berbagi informasi - tugas, pertanyaan, dan materi. Dengan Google Classroom, pengajar dapat menghemat waktu dan kertas. Mereka dapat membuat kelas, memberikan tugas, berkomunikasi, dan melakukan pengelolaan, semuanya di satu tempat. Google Classroom juga menawarkan pengelolaan yang lebih baik. Siswa dapat melihat tugas di halaman Tugas, di aliran kelas, atau di kalender kelas. Semua materi kelas otomatis disimpan dalam folder Google Drive. Selain itu, Google Classroom memungkinkan alur komunikasi antara pengajar dengan murid 
atau antar-murid lebih efektif. Pengajar dapat membuat tugas, mengirim pengumuman, dan memulai diskusi kelas secara langsung. Siswa dapat berbagi materi antara satu sama lain dan berinteraksi dalam aliran kelas atau melalui email. Pengajar juga dapat melihat dengan cepat siapa saja yang sudah dan belum menyelesaikan tugas, serta langsung memberikan nilai dan masukan real-time.

\section{b. Google meet/zoom}

Google Meet dan Zoom memiliki keunggulan fitur yang memudahkan para penggunanya untuk konferensi video, maka segala kegiatan akan lebih mudah untuk dilakukan. Kamu tidak perlu risau dan mengeluh karena keterbatasan akses untuk bertatap muka langsung, karena ada banyak aplikasi konferensi video yang bisa digunakan.

c. WA/telegram

Merupakan fitur yang memudahkan untuk mengirim dan menerima pesan, mengirim gambar, pesan suara, file dan melakukan panggilan video.

\section{d. Youtube}

Merupakan perkumpulan video yang diupload dari berbagai sumber, youtube memungkinkan untuk mencari video tontonan edukasi yg membantu proses belajar mengajar dan hiburan

\section{e. Latop/Hp}

Media digital pntar yang memungkinkan untuk mengakses dan membuat berbagai tugas dan sumber informasi belajar dan mengajar selama daring

\section{f. Kuota internet}

Kuota internet sangat penting dalam pembelajaran daring, ini menjadi faktor utama jika pembelajaran daring dilakukan. Kouta internet juga yang memungkinkan untuk mengakses seluruh media pembelajaran, dan didukung dengan jaringan yang bagus di daerah tersebut. Untuk mengakses sumber-sumber informasi belajar dan mengajar

\section{Tindakan Solutif}

Seorang guru merupakan sosok pengajar sekaligus dalah pemberi arahan dan solusi bagi siwa saat proses belajar mengajar, setiap permasalahan dan kesulitan yang di alami siswa saat belajar makan pengajar menyediakan tindakan solutif, adapun tindakan solutif tersebut antara lain:

a. Jika ada beberapa siswa yang tidak atau belum memiliki alat piranti digital seperti handphone maka setiap siswa dapat meminjam atau membeli perangkat tersebut. Jika masih tidak memungkinkan, siswa dapat menggunakan handphone orang tua masing-masing atau bisa juga berkunjung ke rumah 
teman sejawat untuk belajar bersama serta meminta tolong (meminjam akun instagram) agar dapat menulis teks deskripsi yang nantinya diunggah ke media sosial instagram, namun tetap mencantumkan nama pemilik atau pembuat teks deskripsi, hal ini tentunya sudah diketahui oleh guru. Solusi yang dapat dilakukan oleh guru salah satunya adalah dengan membagi siswa dalam beberapa kelompok (Khasanah, 2018). Dengan hal ini dapat meminimalisir bagi siswa yang belum atau tidak memiliki handphone.

b. Jika ada sebagian siswa yang memiliki kendala dalam hal jaringan, sehingga tidak dapat memposting gambar serta caption teks deskripsi ke media sosial instagram. Maka tindakan solutif yang dapat dilakukan adalah siswa dapat mencari atau mengusahakan di mana sumber atau tempat adanya jaringan yang stabil.

c. Jika tidak adanya atau kurangnya kuota internet atau paket data maka siswa dapat membeli paket data internet atau meminta bantuan hostpot perangkat lain yang terhubung ke jaringan internet hal ini bisa teman, guru ataupun orang tua. Solusi lainnya adalah dengan mencari atau menggunakan Wi-Fi sekitar apabila jaringan tersebut terkoneksi dengan baik.

d. Jika aplikasi belum atau tidak terinstal/terunduh serta terkendala dalam mengoperasikannya maka solusinya guru memberikan arahan atau bimbingan untuk menginstal aplikasi tersebut di App Market atau Play Store di handphone masing-masing sesuai dengan keperluan dan dapat mempelajari cara menggunakannya atau mengoperasikannya dari berbagai macam sumber. Misalnya mencari di google, tutorial YouTube, melalui guru, orang tua, atau teman sejawat yang sudah mahir menggunakan dan atau mengoperasikan media sosial instagram tersebut.

\section{Simpulan}

Dapat disimpulkan bahwa kemampuan bahasa itu dikelompokkan menjadi dua, yaitu kemampuan bahasa pasif-reseptif dan kemampuan bahasa aktif produktif. Kemampuan bahasa pasif reseptif dikaitkan dengan kemampuan menyimak dan kemampuan membaca sedangkan kemampuan berbicara dan kemampuan menulis dikelompokkan kedalam kemampuan aktif produktif. Kegiatan reseptif menyimak dan membaca memiliki persamaan yaitu sama-sama kegiatan yang bertujuan untuk memahami informasi. Keterampilan membaca menjadi dasar membaca yang tercantum adalah menemukan ide pokok dalam 
wacana yang dibaca. Berdasarkan kompetensi dasar tersebut siswa diharapkan: (1) Mampu memahami hakikat dan ciri-ciri ide pokok, (2) Mampu menunjukkan letak ide pokok dalam suatu bacaan pada wacana, (3) Mampu mengungkapkan ide pokok dalam setiap bacaan pada suatu wacana. Pembelajaran menemukan ide pokok itu penting karena untuk dapat memahami apa yang ingin disampaikan oleh penulis, pembaca harus mampu menemukan ide pokok dari bacaan/wacana yang dibaca. Guru diharapkan mampu membangkitkan minat dan semangat siswa dalam proses membaca untuk menemukan ide pokok. Pembelajaran menemukan ide pokok dalam bacaan/wacana telah diajarkan kepada siswa, tetapi pada kenyataannya masih banyak siswa khususnya kelas IV SD yang belum mampu menemukan ide pokok dalam bacaan/wacana dengan benar adapun model pembelajaran yang ditujukan untuk guru sekolah dasar yaitu menggunakan sebuah metode Kegiatan Membaca Berpikir Terarah (Model Directed Reading Thinking Activity) (DRTA), dan di dukung dengan kesiapan pengajar dan siswa, untuk membangun belajar mengajar yang mudah untuk dipahami siswa kelas IV SD dalam menemukan ide pokok dan paragraph. 


\section{Referensi}

Link google

http://repository.unej.ac.id/handle/123456789/22853

http://digilib.unimed.ac.id/7225/8/1104311022\%20Bab\%20I

https://repository.usd.ac.id/35928/1/Pembelajaran\%20Bahasa\%20untuk\%

20SD

https://jatengpos.co.id/circ-tingkatkan-kemampuan-siswa-menentukangagasan-pokok-paragraf/arif/

https://tirto.id/mengenal-google-classroom-fungsi-dan-caramenggunakannya-eG7S

Abidin Yunus. 2012. Pembelajaran Bahasa Berbasis Pendidikan Karakter. Bandung:

Refika Aditama. Alek \& Achmad H. 2011. Bahasa Indonesia Untuk Perguruan Tinggi. Jakarta:

Kencana. Arifin Zaenal \& S. Amran Tasai. 2003. Cermat Berbahasa Indonesia Untuk Perguruan Tinggi. Jakarta:

Akademika Pressindo. Arsyad Azhar. 2011. Media Pembelajaran. Jakarta:

Rajawali Pers. Asnawir. HM dan Usman Basyiruddin. 2002. Media Pembelajaran. Ciputat: Ciputat Pers.

Baharuddin. H Nur Esa Wahyuni. 2010. Teori Belajar \& Pembelajaran. Jogjakarta: Ar-Ruzz Media. Dimyati dan Mudjiono. 2009. Belajar Dan Pembelajaran. Jakarta:

Rineka Cipta. Hidayatullah, Wibowo Wahyu Eko dan Anshori Aan. 2014. Pengembangan Media dan Sumber Belajar. Serang: Lembaga Penjamin Mutu Institut Agama Islam Negeri

Sultan Maulana Hasanuddin Banten. Iskandarwassid dan Sunendar Dadang. 2008. Strategi Pembelajaran Bahasa. Bandung:

PT Remaja Rosdakarya. Mayawati Lina, Ni Nym. Garminah, Nym. Kusmariyatni. 2014. Penerapan Media Kartu Cerita Untuk Meningkatkan Kemampuan Menulis Karangan Narasi Pada Siswa Kelas V Madrasah Ibtidaiyah (MI) Nurun Najah Sumberkima e-Journal MIMBAR PGSD Universitas Pendidikan Ganesha Jurusan PGSD. 
Pangaribuan Tagor. 2008. Paragdigma Bahasa. Yogyakarta: Graham Ilmu. Samidi. 2011. Bahasa Indonesia Untuk SD/MI Kelas IV. Sidoarjo: Masmedia. Sanjaya Wina. 2006. Strategi Pembelajaran Berorientasi Standar Proses Pendidikan. Jakarta: Prenada media.

Santosa Puji. 2009. Materi dan Pembelajaran Bahasa Indonesia SD. Jakarta: Universitas Terbuka.

Sudjana Nana dan Rivai Ahmad. 2013. Media Pengajaran. Bandung: Sinar Baru Algensindo. Suprijono Agus. 2012. Cooperative learning Teori dan Aplikasi PAIKEM. Yogyakarta: Pustaka Belajar.

Susanto Ahmad. 2013. Teori Belajar dan Pembelajaran di Sekolah Dasar. Jakarta: Prenadamedia Group. Syah Darwan, Supardi, dan Muslihah Eneng. 2009. Strategi Belajar Mengajar. Jakarta: Diadit Media. Syah Muhibbin. 2013. 


\section{*Data Penulis}

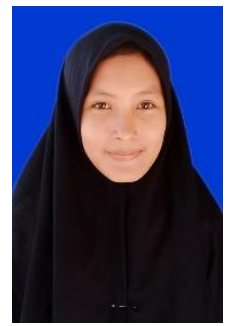

Nuraini lahir di Bangko Jaya, 26 Mei 2002. Pada tahun 2020 sampai sekarang, ia melanjutkan studi di Perguruan Tinggi dengan program studi Pendidikan Bahasa dan Sastra Indonesia FKIP Universitas Riau melalui jalur SNMPTN (Seleksi Nasional Masuk Perguruan Tinggi Negeri).

Kontak:

$\mathrm{Hp} / \mathrm{Wa}: 082384631727$

Email : nuraini0603@student.unri.ac.id 